\title{
Toward equality of biodiversity knowledge through technology transfer
}

\section{Running head: Biodiversity technology transfer}

Monika Böhm ${ }^{1 *}$ and Ben Collen ${ }^{2}$

1 - Institute of Zoology, Zoological Society of London, Regent's Park, London NW1 4RY, United Kingdom.

2 - Centre for Biodiversity \& Environment Research, University College London, Gower Street, London WC1E 6BT, United Kingdom.

* correspondence: monika.bohm@ioz.ac.uk; +44(0)207 4496676

Keywords: Convention on Biological Diversity; Aichi Targets; indicators; knowledge transfer; capacity building; Access and Benefit sharing

Word count: 5,999 


\section{Abstract}

To help stem the continuing decline of biodiversity, effective transfer of technology from resource-rich to biodiversity-rich countries is required. Biodiversity technology as defined by the Convention on Biological Diversity (CBD) is a complex term, encompassing a wide variety of activities and interest groups. As yet, there is no robust framework by which to monitor the extent to which technology transfer might benefit biodiversity. We devised a definition of biodiversity technology and a framework for the monitoring of technology transfer between CBD signatories. Biodiversity technology within the scope of the CBD encompasses hard and soft technologies that are relevant to the conservation and sustainable use of biodiversity, or make use of genetic resources, and which relate to all aspects of the CBD, with a particular focus on technology transfer from resource-rich to biodiversity-rich countries. Our proposed framework introduces technology transfer as a response indicator: we increase technology transfer to stem pressures on biodiversity. We suggest an initial approach of tracking technology flow between countries; charting this flow is likely to be a one-to-many relationship (i.e., the flow of a specific technology from one country to multiple countries). Future developments should then focus on integrating biodiversity technology transfer into the current pressure-state-response (i.e., measuring the influence of technology transfer on changes in state and pressure variables) indicator framework favored by the CBD. Structured national reporting is important to obtaining metrics relevant to technology and knowledge transfer. Interim measures that can be used to assess biodiversity technology or knowledge status while more in-depth indicators are being developed include the number of species inventories, threatened species lists, or national red lists, while databases on publications and project funding may provide measures of international cooperation. Such a pragmatic approach, followed by rigorous testing of specific technology transfer metrics submitted by CBD signatories in a standardized manner, may in turn improve the focus of 
future targets on technology transfer for biodiversity conservation. 


\section{Introduction}

The Convention on Biological Diversity (CBD) 2010 target assessment clearly showed that biodiversity continues to decline and that pressures driving this loss are increasing in magnitude and scope (Butchart et al. 2010). A mid-term review of the CBD Aichi Targets showed little progress in the subsequent 5 years, and modeled projections make target adherence unlikely by 2020 (Tittensor et al. 2014). Technology and knowledge transfer between countries has been increasingly hailed as one of the most important mechanisms by which to address environmental issues. However, direct measurement of the impact of knowledge sharing and its benefits to biodiversity have lagged behind these calls. Yet in international development, technical cooperation tends to accelerate technological catch-up among nations (Sawada et al. 2010), while other studies link specific conservation strategies that include technology transfer with successful conservation outcomes, at least at the project level (e.g., Howe \& Milner-Gulland 2012).

Technology transfer has become a key ingredient of international environmental policy (e.g., United Nations Framework Convention on Climate Change [UNFCCC]; Intergovernmental Platform on Biodiversity and Ecosystem Services [IPBES]). The need for technology and knowledge transfer has been recognized by the CBD since its inception; they note that parties are "aware of the general lack of information and knowledge regarding biological diversity and of the urgent need to develop scientific, technical and institutional capacities to provide the basic understanding upon which to plan and implement appropriate measures" (CBD 1992). The convention highlights technology transfer several times, specifically with regard to research and training (Article 12), access to and transfer of technology (Article 16), exchange of information (Article 17), technical and scientific cooperation (Article 18), and handling of biotechnology and distribution of its benefits (Article 19) (CBD 1992). Technology transfer has been encapsulated in the CBD 2020 
strategic plan and Aichi biodiversity targets, particularly Aichi Target 19 ("By 2020, knowledge, the science base and technologies relating to biodiversity, its values, functioning, status and trends, and the consequences of its loss, are improved, widely shared and transferred, and applied" [CBD 2010a]).

Despite this acknowledgement of the importance of biodiversity technology transfer among signatories, reporting on progress in this area has been scant, probably due to the vagueness of target wording and the lack of a succinct definition of biodiversity technology. Here, we argue that there is a distinct need to systematically monitor biodiversity technology transfer. We considered the nature of biodiversity technology in order to build a framework for the development of a set of technology transfer metrics to track progress for specific forms of technology transfer. We also examined how biodiversity knowledge and technology transfer might be monitored in a CBD context.

\section{Concepts and definition of biodiversity technology transfer}

The CBD target framework has resulted in identification of key metrics of biodiversity to be used as a basis for the development of a series of biodiversity indicators. A lot of work remains (Mace \& Baillie 2007; Walpole et al. 2009), particularly in light of the new Aichi targets (Stuart \& Collen 2013; Tittensor et al. 2014). Factors inhibiting consistent reporting on biodiversity technology transfer are the lack of a clear definition of biodiversity technology, the large number and variety of activities comprising biodiversity technology as currently defined by the CBD, and a general lack of technology needs assessments (Pisupathi 2010; Chandra \& Idrisova 2011).

In its widest sense, technology is information put to use to accomplish a specific task (Eveland 1987) and is often thought of as hardware. The term also includes soft technologies 
(e.g., the knowledge needed to use the hardware component appropriately) (Rogers 2002). The CBD includes technologies that address all of its aims and goals; as a result, biodiversity technology-as defined by the CBD - is a complex construct, involving both hard and soft technologies that are relevant to the conservation and sustainable use of biodiversity or make use of genetic resources and do not cause significant damage to the environment (R. Höft \& M. Lehmann, personal communication). The term therefore refers to both hard and soft technologies relating to in situ and ex situ conservation; sustainable management of biodiversity resources; monitoring techniques; modern biotechnologies that use genetic resources; benefit sharing and access to research results (Table 1) (CBD 2010c). For example, biodiversity technologies relating to species monitoring could include both hardware used for the monitoring work itself (e.g. camera traps, acoustic monitoring equipment) and the knowledge to use the hardware and carry out meaningful species surveys. This knowledge can be contained in peer-reviewed literature or transferred through webbased learning or workshops.

The matter of defining biodiversity technology is further complicated because its 5 broad constituent parts are not mutually exclusive (e.g., monitoring is an integral part of in situ conservation), and some of the sub-components themselves have very broad definitions. For example, sustainable resource use is broadly defined because it lacks adequate terminology to distinguish between the various concepts falling within its remit (e.g., use, sustainability, and incentives) (Hutton \& Leader-Williams 2003) and combines biological, social, cultural, and economic factors (Milner-Gulland \& Rowcliffe 2007). Technologies may include a wide range of management techniques, from participatory approaches and economic incentives to assessments of present sustainability of systems and predictive scenario modeling. 
Other forms of biodiversity technology relating to modern biotechnologies and access and benefit sharing are covered under the legally binding framework of the Nagoya Protocol on Access to Genetic Resources and the Fair and Equitable Sharing of Benefits Arising from their Utilization (ABS) to the Convention on Biological Diversity. This document urges parties to "promote and encourage access to technology by, and transfer of technology to, developing country parties" (Secretariat of the Convention on Biological Diversity 2011). However, examples of technology transfer stemming from access and benefits sharing (ABS) agreements are still few and far between (Secretariat of the Convention on Biological Diversity 2008). Botanic gardens transferring germ plasms between countries is an example where technology transfer as part of ABS agreements is already taking place (e.g., CBD 2010d).

Technology is transferred between one or more persons or organizations and via diverse activities. Examples include correspondence, training, workshops, conferences, databases, publications, project funding, and technology sourcing. Some technologies may therefore be directly transferred between specific individuals or organizations, while others may be transferred indirectly to a large number of people (e.g., through open-access publications).

Technology transfer has often been viewed as a unidirectional linear process from producer to recipient (Cottrill et al. 1989; Rogers 2002). Therefore, in its simplest format, technology flows from countries harboring biodiversity technology to countries where biodiversity technology is needed (Fig. 1a). However, most often, the transfer process is at least bidirectional (i.e., technology flows in both directions), for example, through cooperation. When considering the diffusion of soft technology (e.g., knowledge exchange), the flow of technology may become a one-to-many relationship or a multidirectional one that involves co-production of knowledge (Fazey et al. 2012), making simple flows of technology 
from technology-rich to technology-poor countries unrealistic. This is particularly the case for cooperative networks (e.g., biodiversity observation networks [Scholes et al. 2008] and knowledge networks that are crucial for the effective dissemination of knowledge on sustainable development [Arungu-Olende 2007]).

Monitoring of progress toward set targets greatly depends on policy context. The majority of technical knowledge and biodiversity data continue to be held in temperate regions (Collen et al. 2008), but the largest declines in wildlife; highest abundance and diversity; and most significant data gaps are in the tropics (Collen et al. 2009; Giam et al. 2012). Rapid transfer of biodiversity knowledge, technology, and training is therefore needed from resource-rich countries to biodiversity-rich countries (Balmford et al. 2002; Smith et al. 2003). The imbalance that exists in biodiversity technology due to economic differences between countries has been recognized by the CBD ( 1992). We focus on this direction of transfer because it is the flow direction most likely to help safeguard the world's biological diversity that is most prominently referred to in the CBD (Fig. 1a). However, the traditional view of north-south technology transfer (e.g., from resource-rich to biodiversity-rich countries in the original context of the CBD) is being challenged increasingly because southsouth technology transfer is growing in importance. It is likely that, in future, south-south transfer will require greater attention as more agreements are made to foster these interactions. Many of the issues and concepts we discuss apply equally to north-north or south-south transfer.

Countries with high-income economies may interchange technology due to collaboration in research and development, while others may use buying power to obtain technology rather than develop it themselves. Technology may be sent from high-income economies to low-income economies, especially in the context of the $\mathrm{CBD}$, and vice versa (Fig. 1b). It is likely that technology transfer is more frequent among countries with 
economic, geographic, cultural, or historic ties. Thus, countries are likely to differ in the level of involvement in technology transfer. Quantification of this involvement would be useful to identify gaps in technology transfer, although these gaps would need to be assessed in relation to what a country can contribute to (or needs to receive from) the technology pool. For example, country A (Fig. 1b) is involved in technology development and transfer at all levels through cooperation and collaboration and provides one-way transfer to low-income countries. Other countries may only convey the technology they receive from another country as part of a commitment to aid agreements or development policies, yet they may not necessarily develop the technology themselves (e.g., country C). Within a CBD context, we would also include the latter because this strengthens the country's commitment to the convention.

\section{Measuring biodiversity technology transfer}

\section{Stock and flow metrics}

Technology transfer can be measured using both stocks and flows, although until now most metrics have focused on stock assessments of available technology (for example in research and development) (Keller 2004; Sawada et al. 2010). Stock metrics are taken at a single point in time, for example the number of patents existing at a given time. There has been much discussion about how to measure technology transfer within a CBD context, specifically for the complex subject of sustainable development. Yet as in research and development, assessment of science and technology activities for sustainable development primarily focuses on simple stock assessments of activities or projects, funding, ideas, and technologies

(Gault 2007). There are more than 500 indicators dealing with the diverse aspects of sustainable development (Parris \& Kates 2003; Böhringer \& Jochem 2007; Gault 2007; United Nations 2007), many of which are based on stock assessments. 
Flow metrics generally refer to measurements taken over time, say number of patent applications over a year. However, when considering technology transfer, this concept can be adapted to not only reflect flow over time but also - in a geographical sense - to reflect flow from donor to recipient. This enables assessment of which countries send and receive which type of technology and hence effectiveness of flows in addressing biodiversity issues, and the identification of significant gaps. Measuring such flows has proved intractable in other areas of biodiversity research, for instance ecosystem services, where services may be provided in one place while the benefits accrue elsewhere. In the context of technology transfer, simple stock assessments may incorporate the spatial aspect of flow direction through systematic collection of ancillary data on the countries or organizations receiving technology and the quantity of technology they receive. For example, indicators for cooperation (as a specific form of technology transfer) can be based on co-publication or co-patenting, movement of human resources across borders, grants and contracts, and direct investment in cooperation (Gault 2007). Again, most of these are stock assessments (unless assessed over time), although movement of human resources across borders is clearly attempting to quantify spatial flow of technology and knowledge.

\section{Metrics of biodiversity technology transfer}

For meaningful indicator development, measurements need to be target specific; however, technology transfer targets within the CBD context are currently very broad and ill-defined. The consequence has been slow development of a set of comprehensive indicators tracking the technology transfer response of resource-rich countries to the technology needs of resource-poor countries. Similarly, indicators to track the status and impacts of access and benefit sharing agreements have not yet been determined (Biodiversity Indicators Partnership 2013). However, a number of currently implemented indicators pertaining to Goal $\mathrm{E}$ of the 
CBD's Strategic Plan attempt to gauge status of technology worldwide, for example via the number of global biodiversity information facility (GBIF) records over time (Biodiversity Indicators Partnership 2013) (Table 2). Other indicators under development focus on the number of maintained species inventories used to implement the CBD (Biodiversity Indicators Partnership, 2013). Official development assistance provided in support of the $\mathrm{CBD}$ is currently the only indicator containing information about flow between donors and recipients (Biodiversity Indicators Partnership 2013). However, only a fraction of these resources will directly contribute to biodiversity technology transfer. Disentangling this contribution is likely to be difficult, although much can be learned from welfare economics in how to approach the issue (e.g. Patel et al. 2009). Recently, a new indicator has been proposed that would focus on the coverage of sub-global assessments that include related capacity building and knowledge transfer. However, very little is published about the practical aspects of this proposed indicator, and the method is still in development (CBD 2013).

Current, proposed, and plausible indicators for the main aspects of technology transfer are summarized in Table 2. Although suggested indicators focus specifically on the volume of biodiversity technology transfer, the expenditure contributing to technology transfer (e.g., from development projects), or the frequency of technology improvements (mostly spatial flow assessments), implemented indicators primarily focus on the availability of current biodiversity technology across the globe (mostly stock assessments).

Stock measures are often used as a proxy for flow indicators, primarily because metrics of stock are more easily obtained (Layke et al. 2012). In the context of the CBD, the ease of stock measure development needs to be weighed against the need to provide measures of flow between signatory countries. More detailed knowledge of the flows of technology 
between countries will allow us to ask more complex questions about providers and recipients of technology transfer than a simple stock assessment would.

Ultimately, it is paramount that metrics allow the assessment of the contribution of technology to improved biodiversity conservation. This aspect is important because technology transfer is not only about the application of a technology into use but also about what happens as a result of this application (Rogers 2002), through monitoring of the exchange, or diffusion, of knowledge (Beal et al. 1986).

\section{Indicator framework}

There is an urgent need to develop indicators to track biodiversity technology transfer and progress toward technology transfer targets and to assess the outcomes of technology transfer schemes on biodiversity status. Such indicators need to be cost-effective, reliable, and informative in terms of their ability to capture status and trends at a number of scales. They also need to accommodate frequent updating and policy changes and be linkable to policy responses (Jones et al. 2011; Nicholson et al. 2012). Cost-effectiveness is of particular concern in order to avoid redirection of valuable resources from on-the-ground conservation action. Additionally, advanced indicators need to contain information about flow directions and ideally encompass different transfer activities. To be relevant to different stakeholder and tractable for policy makers and the public, sub-structuring of the concept of biodiversity technology may become particularly important. This substructure could, for example, follow the 5 components of biodiversity technology within the CBD (see Table 1). These 5 components necessarily leave out certain aspects of the CBD that may also involve biodiversity technology, albeit in a less tractable manner, particularly those relating to the mainstreaming of biodiversity. Above all, indicator development depends on the availability of primary monitoring data, which may be specific to certain forms or components of 
biodiversity technology and in turn can feed into a single or composite metric (Jones et al. 2011). For simplicity, we recommend focusing solely on direct technology transfer because indirect technology transfer (e.g., where research and development cooperation supports education universally) are prohibitively difficult to define and measure (Gault 2007).

The development of robust and integrated quantitative measures to track progress toward global biodiversity targets has grown over recent decades, specifically the linkage between individual measureable indicators and the inter-related effects of biodiversity trends and policy implementation (e.g., Sparks et al. 2011; Nicholson et al. 2012). This interrelatedness frequently follows the pressure-state-response (PSR) model (OECD 1993), which describes the pressure on the environment, the state of the environment, and the responses to reduce the pressure. For example, an indicator suite for the assessment of biological invasions includes indicators of pressure (number of invasive species), state (trends in extinction risk due to invasive species), and response (international and national policy adoption) (McGeoch et al. 2010). Integrated indicator sets such as these have the advantage of providing a means to both assess how policy has influenced biodiversity outcomes and to assess effectiveness of different policy scenarios into the future (Sparks et al. 2011).

However, many global biodiversity targets tend to be less specific, making it difficult to align metrics and indicators with these targets (Collen \& Nicholson 2014), something which is particularly true for Aichi Target 19 on technology and knowledge transfer. There is a clear danger that poor alignment between PSR indicators will result in misleading conclusions about the cause and effect of biodiversity change. For example, an analysis of progress toward the 2010 biodiversity targets shows that while response indicators have been increasing dramatically, all status indicators are in decline (Butchart et al. 2010). Collating measurable outputs, for which data exist or can be collected, is a pragmatic first step to tracking progress toward increasing technology transfer. These are likely to be predominantly 
independent state metrics (i.e., measuring status of biodiversity knowledge and technology, such as GBIF records [Biodiversity Indicators Partnership 2013]) that fall outside the CBDfavored PSR framework. However, given the uncertainty of links between technology transfer and biodiversity benefits, the advantage of these simple independent measures is that data may be more easily obtained and understood and interpreted by practitioners and policy makers. This pragmatic approach, followed by rigorous testing of metrics, may also improve the focus of future technology transfer targets.

Biodiversity technology transfer metrics would ultimately have to be incorporated into the current CBD indicator framework, which follows the PSR model. There are a number of ways in which this could be achieved. The first is as a response indicator. Pressures drive changes in biodiversity (the state), as a result of which response is increased through technology transfer, specifically to those places where pressures are particularly high (Fig. 2a). Metrics may relate to stock assessments of technology, such as the number of projects with technology transfer components, expenditure or investment in developing or obtaining technology, and investment in providing or receiving training in technology (Fig. 2b). To incorporate flow into this simple framework of technology stock measurements, ancillary data on donors and recipients and related relevant metrics between donors and recipients (e.g., human resources training or trained; expenditure of donor country) (Fig. 2b).

The more ambitious goal for incorporating biodiversity technology transfer is to use it in a more integrated manner in the PSR cycle by measuring the influence of technology transfer on each part of the PSR framework. For example, in a typical PSR cycle (Fig. 2a), one could assess the influence of biodiversity technology transfer on changes in the measure of state and pressure over time (e.g., the direct influence of biodiversity technology transfer on the state of biodiversity or pressures on species and habitats, i.e. how technology transfer influences threat reduction) and on other response metrics (e.g., how biodiversity technology 
transfer has affected the extent of protected areas or production of high-quality national biodiversity strategies and action plans). This approach assumes that technology transfer has a direct and measurable effect on biodiversity (positive) and threats to it (negative), although at present, to our knowledge, no quantitative studies exist to link technology transfer to biodiversity benefits. As a result, it is unlikely that this more ambitious goal could be achieved for broad-scale biodiversity metrics within a reasonable time frame, but it may be particularly informative for specific metrics that could in turn help inform other CBD indicators and capacity building activities (e.g., those relevant to biodiversity and species monitoring components).

\section{Data sources and the importance of national reporting}

Existing reporting mechanisms are likely to provide the most efficient and standardized manner in which to gather vital metrics of technology transfer in line with our framework (Fig. 2b). Signatories to the CBD are bound by article 26 to report at intervals to the secretariat "on measures which it has taken for the implementation of the provisions of this Convention and their effectiveness in meeting the objectives of this Convention" (CBD 1992). Hence, national reporting provides the most likely vehicle for data collection on ongoing technology transfer initiatives, and it has been proposed that information from national reports be used for building a set of indicators (Pisupathi 2010). However, this requires clearly defined reporting requirements in order to derive optimal data from national reports.

The fifth national reports of parties was set to focus on the implementation of the 2011-2020 Strategic Plan for Biodiversity and the progress toward the Aichi Biodiversity Targets (CBD 2010b). However, at present, national reporting does not successfully fulfil its obligation of reporting on progress toward technology transfer targets. National reporting has 
in the past included a mixture of basic qualitative capacity or technology needs assessments, expenditure on or receipt of foreign aid, and quantitative statements on the number of technology transfer initiatives, sometimes accompanied by specific examples. However, an analysis of the third national reports showed that more than half of countries had not yet completed their technology needs assessment (Chandra \& Idrisova 2011), suggesting that even the most basic data to inform technology transfer targets are lacking. Standardization of national reporting with respect to technology transfer and technology needs assessments is likely to provide valuable data to construct a suitable indicator for tracking the status of technology transfer. To achieve this, some standard measures need to be introduced together with indications of flow between specific countries (Fig. 2b).

Obtaining the data necessary for indicator development requires tapping into information held by key players in technology transfer, as was shown by a recent U.K. assessment (Böhm \& Collen 2011). The main difficulty lies in obtaining meaningful information. For example, just over $60 \%$ of surveyed organizations provided quantitative information, such as the proportion of projects with a technology transfer component and the proportion of full time equivalent staff working on technology transfer projects (Böhm \& Collen 2011). Even fewer respondents provided information on the average spending per technology transfer project (Böhm \& Collen 2011).

Because biodiversity technology transfer initiatives rely on funding, it is likely that databases of funding bodies that engage in technology transfer activities could provide reasonable information on existing initiatives within a national context. Funding bodies with outcomes aligned toward the implementation of international convention targets such as those of the CBD would be the most beneficial (e.g., Darwin Initiative 2014). However, to be of use in the development of more detailed metrics of technology transfer, data need to be collected systematically by project funding bodies (Howe \& Milner-Gulland 2012). In many 
cases, funders' reports focus on project outputs (which are specific activities delivered by a project) instead of project outcomes, which measure conservation improvements but are much more difficult to quantify given the fact that they are often not measurable over project time frames (Salafsky \& Margoluis 1999; Howe \& Milner-Gulland 2012). However, well-run funding bodies may allow the assessment of project outputs and outcomes and factors influencing them through their reporting (Howe \& Milner-Gulland 2012).

While funding databases may provide direct data on projects related to the implementation of the $\mathrm{CBD}$, expenditure on biodiversity technology transfer represents only one small component of overall funding, and disentangling the contribution of technology transfer toward the overall total expenditure of a project may not be straightforward. As a result, increasing expenditure may not have a one-to-one relationship with increasing biodiversity technology transfer. The appropriateness of using funding databases to assess technology transfer should be explored, keeping in mind the contribution of welfare economics focusing on disentangling and tracking funding expenditure (e.g., Patel et al. 2009). If they prove useful, then recommendations should be made on standardizing reporting from funders of technology transfer activities to fulfill needs of indicator development.

Collaboration among researchers from different countries may also include technology transfer by promoting knowledge exchange between institutions. Co-publications present another potential measurement of technology transfer (Gault 2007). Through citation databases, obtaining co-publication rates and global coverage of co-publication for different countries or specifically different sectors relevant to the CBD (e.g., in the field of biodiversity monitoring) is becoming increasingly straightforward. Again, it is vital that the suitability of these possible indicators of knowledge transfer be tested rigorously.

\section{Discussion and next steps}


Technology transfer forms an integral part of the CBD and is of particular importance for developing countries, which are often resource poor but biodiversity rich. As defined by the CBD, technology transfer brings together hard and soft technologies that further CBD's three main objectives: conservation of biological diversity, sustainable use thereof, and fair and equitable sharing of its benefits. Thus, the concept of biodiversity technology involves a number of very different components, a diversity of means by which transfer of technology can be achieved, and a large number of different stakeholders contributing to the generation and transfer of technology. With targets set to improve the sharing of biodiversity technology by 2020 , it is not only vital to track trends in the levels of biodiversity technology transfer but also to establish a baseline level against which to assess future trends. Conceptually it is possible to integrate a technology transfer indicator into the PSR framework favoured by the CBD, though its implementation seems some way off.

While our effort represents a first step in developing a framework for indicators of biodiversity technology transfer, some potential mechanisms for data collection on technology transfer activities exist. National reporting to the CBD could provide the vehicle for more targeted information being submitted by each signatory. Project funding databases may provide information on project expenditure and activities, and on who is involved in technology transfer. Given this potential wealth of data sources, the next step is to carry out an in-depth analysis of the usefulness of these data for indicator purposes, particularly with regard to their sensitivity as indicators.

The availability of data on the metrics of choice most often represents the limiting factor to effective indicator development. The complex nature of technology transfer embraces widely different transfer activities and, when considering flow measures, may be highly spatially patterned. Many of the potential metrics of technology transfer are difficult to obtain, and establishing their impact on the status of biodiversity - the ultimate aim of such 
an endeavor - is complex. As a result biodiversity knowledge indicators at present often focus on easy-to-measure components, such as the availability of species inventories, threatened species lists, or national red lists and national biodiversity strategies and action plans. While more comprehensive indicators are being developed, these existing data may be used to describe the state of biodiversity knowledge and may function as a technology or knowledge needs assessment. Measures drawn from funding providers could also be fasttracked to provide timely metrics. Without significant investment, in-depth indicators with the type of causal links implied by the PSR framework are unlikely to be developed in time for the Aichi Target assessment in 2020. Given the importance of biodiversity technology in both measuring and achieving the targets set by the CBD, research effort toward establishing such links is vital.

\section{Acknowledgments}

This work stems from a project funded by Defra (grant WC1006/CR0498). B.C. and M.B. were partly supported by the Rufford Foundation. B.C. is an honorary research fellow at United Nations Environment Programme World Conservation Monitoring Centre. The Zoological Society of London is part of the Biodiversity Indicators Partnership (www.bipindicators.net). A previous version of the manuscript was greatly improved through the feedback of two anonymous reviewers.

\section{Literature Cited}

Arungu-Olende, S. 2007. Developing knowledge infrastructure and networks for sustainable development. Pages 101-106 in Integrating Science \& Technology into Development Policies: An International Perspective. OECD/Department of Science and Technology, OECD Publishing, South Africa. 
Balmford, A., et al. 2002. Economic reasons for conserving wild nature. Science 297: 950953.

Beal, G.M., W. Dissanayake, and S. Konoshima. 1986. Knowledge generation, exchange, and utilization. Westview Press, Boulder, Colorado.

Biodiversity Indicators Partnership. 2013. The indicators. Available from http://www.bipindicators.net/globalindicators (accessed December 2013).

Böhm, M., and B. Collen. 2011 Rapid review of biodiversity technology transfer in the United Kingdom: a report to DEFRA. Institute of Zoology, Zoological Society of London, London.

Böhringer, C., and P.E.P. Jochem. 2007. Measuring the immeasurable - a survey of sustainability indices. Ecological Economics 63: 1-8.

Butchart, S.H.M., et al. 2010. Global biodiversity: indicators of recent declines. Science 328: 1164-1168.

CBD. 1992. The Convention on Biological Diversity. Available from http://www.cbd.int/doc/legal/cbd-en.pdf (accessed February 2011).

CBD. 2010a. Strategic Plan for Biodiversity 2011-2020. Available from http://www.cbd.int/decision/cop/?id=12268 (accessed June 2014).

CBD. 2010b. COP 10 Decision X/10: National reporting: review of experience and proposals for the fifth national report. Available from https://www.cbd.int/decision/cop/default.shtml?id=12276 (accessed January 2014).

CBD. 2010c. Factsheet: Technology Transfer and Technological and Scientific Cooperation. Available from http://www.cbd.int/iyb/doc/prints/factsheets/iyb-cbd-factsheet-tttcen.pdf (accessed March 2011).

CBD. 2010d. Updated Global Strategy for Plant Conservation 2011-2020. Available from http://www.cbd.int/gspc/strategy.shtml (accessed November 2013). 
CBD. 2013. Strategic Plan Indicators. Available from http://www.cbd.int/sp/indicators/ (accessed December 2013).

Chandra, A., and A. Idrisova. 2011. Convention on Biological Diversity: a review of national challenges and opportunities for implementation. Biodiversity and Conservation 20: $3295-3316$.

Collen, B., and E. Nicholson. 2014. Taking the measure of change. Science 346: 166-167.

Collen, B., M. Ram, T. Zamin, and L. McRae. 2008. The tropical biodiversity data gap: addressing disparity in global monitoring. Tropical Conservation Science 1: 75-88.

Collen, B., J. Loh, L. McRae, S. Whitmee, R. Amin, and J.E.M. Baillie. 2009. Monitoring change in vertebrate abundance: the Living Planet Index. Conservation Biology 23: $317-327$.

Cottrill, C.A., E.M. Rogers, and T. Mills. 1989 Co-citation analysis of the scientific literature of innovation research traditions: diffusion of innovations and technology transfer. Science Communication 11: 181-208.

Darwin Initiative. 2014. The Darwin Initiative. Available from http://www.darwininitiative.org.uk/project/ (accessed January 2015).

Eveland, J.D. 1987. Diffusion, technology transfer, and implementation. Knowledge 8: 303322.

Fazey, I., et al. 2012. Knowledge exchange: a review and research agenda for environmental management. Environmental Conservation 40: 19-36.

Gault, F. 2007. Assessing international S\&T co-operation for sustainable development: towards evidence-based policy. Pages $107-114$ in Integrating Science \& Technology into Development Policies: An International Perspective. OECD/Department of Science and Technology, OECD Publishing, South Africa. 
Giam, X., B.R. Scheffers, N.S. Sodhi, D.S. Wilcove, G. Ceballos, and P.R. Ehrlich. 2012. Reservoirs of richness: least disturbed tropical forests are centres of undescribed species diversity. Proceedings of the Royal Society B-Biological Sciences 279: 67-76.

Howe, C., and E.J. Milner-Gulland. 2012. Evaluating indices of conservation success: a comparative analysis of outcome- and output-based indices. Animal Conservation 15: 217-226.

Hutton, J.M., and N. Leader-Williams. 2003. Sustainable use and incentive-driven conservation: realigning human and conservation interests. Oryx 37: 215-226.

Jones, J.P.G., et al. 2011 The Why, What, and How of Global Biodiversity Indicators Beyond the 2010 Target. Conservation Biology 25: 450-457.

Keller, W. 2004. International technology diffusion. Journal of Economic Literature 42: 752782.

Layke, C., A. Mapendembe, C. Brown, M. Walpole, and J. Winn. 2012. Indicators from the global and sub-global Millennium Ecosystem Assessments: an analysis and next steps. Ecological Indicators 17: 77-87.

Mace, G.M., and J.E.M. Baillie. 2007. The 2010 Biodiversity Indicators: Challenges for Science and Policy. Conservation Biology 21: 1406-1413.

McGeoch, M.A., S.H.M. Butchart, D. Spear, E. Marais, E.J. Kleynhans, A. Symes, J. Chanson, and M. Hoffmann. 2010 Global indicators of biological invasion: species numbers, biodiversity impact and policy responses. Diversity and Distributions 16: 95-108.

Milner-Gulland, E.J., and J.M. Rowcliffe. 2007. Conservation and sustainable use: a handbook of techniques. Oxford University Press, Oxford, UK.

Nicholson, E., et al. 2012. Making robust policy decisions using global biodiversity indicators. PLoS One 7 (e41128) DOI: 10.1371/journal.pone.0041128 
OECD. 1993. OECD core set of indicators for environmental performance reviews - a synthesis report by the Group on the State of the Environment. OECD Environment Monographs No. 83. Organisation for Economic Co-operation and Development (OECD), Paris, France.

Parris, T.M., and R.W. Kates. 2003. Characterizing and measuring sustainable development. Annual Review Environmental Resources 28: 559-586.

Patel, P., B. Roberts, S. Guy, L. Lee-Jones, and L. Conteh. 2009. Tracking Official Development Assistance for reproductive health in conflict-affected countries. PLoS Medicine 6:e1000090. DOI: 10.1371/journal.pmed.1000090.

Pisupathi, B. 2010 Technology transfer and cooperation under the Convention on Biological Diversity: towards more effective implementation. Division of Environmental Law and Conventions, United Nations Environment Programme, Kenya.

Rogers, E.M. 2002. The nature of technology transfer. Science Communication 23: 323-341. Salafsky, N., and R. Margoluis. 1999. Threat reduction assessment: a practical and cost effective approach to evaluating conservation and development projects. Conservation Biology 13: 830-841.

Sawada, Y., A. Matsuda, and H. Kimura. 2010. On the role of technical cooperation in international technology transfers. Journal of International Development 24: 316-340.

Scholes, R.J., G.M. Mace, W. Turner, G.N. Geller, N. Jürgens, A. Larigauderie, D. Muchoney, B.A. Walther, and H.A. Mooney. 2008. Toward a global biodiversity observing system. Science 321: 1044-1045.

Secretariat of the Convention on Biological Diversity. 2008. Access and Benefit-Sharing in practice: trends in partnerships across sectors. Secretariat of the Convention on Biological Diversity, Montréal, Canada. 
Secretariat of the Convention on Biological Diversity. 2011. Nagoya Protocol on access to genetic resources and the fair and equitable sharing of benefits arising from their utilization to the Convention on Biological Diversity - text and annex. Secretariat of the Convention on Biological Diversity, Montréal, Canada.

Smith, R.J., R.D.J. Muir, M.J. Walpole, A. Balmford, and N. Leader-Williams. 2003. Governance and the loss of biodiversity. Nature 426: 67-70.

Sparks, T.H., et al. 2011 Linked indicator sets for addressing biodiversity loss. Oryx 45: 411419.

Stuart, S.N., and B. Collen. 2013. Conserving biodiversity in a target driven world. Pages 421-438 in B. Collen, N. Pettorelli, J.E.M. Baillie and S. Durant, editors. Biodiversity Monitoring \& Conservation: Bridging the gap between global commitment and local action. Wiley-Blackwell, Cambridge, UK.

Tittensor, D.P., et al. 2014. A mid-term analysis of progress toward international biodiversity targets. Science 346: 241-244.

United Nations. 2007. Indicators of sustainable development: guidelines and methodologies. $3^{\text {rd }}$ edition. United Nations, New York.

Walpole, M., et al. 2009. Tracking progress toward the 2010 biodiversity target and beyond. Science 325: 1503-1504.

World Bank. 2015. Country and Lending Groups. Available from http://data.worldbank.org/about/country-and-lending-groups (accessed January 2015). 
Table 1. Activities involving biodiversity technology transfer.

\begin{tabular}{|c|c|c|}
\hline Activity & Definition & Examples \\
\hline In situ and ex situ conservation & $\begin{array}{l}\text { conservation management of } \\
\text { units of biodiversity (most } \\
\text { often species) inside or } \\
\text { outside their natural habitat }\end{array}$ & $\begin{array}{l}\text { species action plans, } \\
\text { species management, } \\
\text { habitat management, } \\
\text { protected area } \\
\text { management, threat } \\
\text { mitigation (e.g. human- } \\
\text { wildlife conflict), } \\
\text { breeding programs }\end{array}$ \\
\hline $\begin{array}{l}\text { Sustainable use of biodiversity } \\
\text { resources }\end{array}$ & $\begin{array}{l}\text { use of components of } \\
\text { biological diversity in a way or } \\
\text { at a rate that does not lead to } \\
\text { the long-term decline of } \\
\text { biological diversity }\end{array}$ & $\begin{array}{l}\text { participatory approaches, } \\
\text { economic incentives, } \\
\text { livelihood approaches, } \\
\text { assessments of present } \\
\text { sustainability of systems, } \\
\text { predictive models of use } \\
\text { scenarios }\end{array}$ \\
\hline Biodiversity monitoring & $\begin{array}{l}\text { monitoring at all spatial scales, } \\
\text { from local to global, and from } \\
\text { species to population or } \\
\text { ecosystem-level }\end{array}$ & $\begin{array}{l}\text { geographical information } \\
\text { systems, satellite } \\
\text { mapping, camera } \\
\text { trapping, remote tracking } \\
\text { devices, smart phone } \\
\text { technologies, ranger- } \\
\text { based monitoring, } \\
\text { national red lists }\end{array}$ \\
\hline $\begin{array}{l}\text { Biotechnologies using genetic } \\
\text { resources }\end{array}$ & $\begin{array}{l}\text { biotechnologies to research } \\
\text { beneficial properties of genetic } \\
\text { resources, develop commercial } \\
\text { products, further scientific } \\
\text { understanding }\end{array}$ & $\begin{array}{l}\text { crop protection, drug } \\
\text { development, taxonomic } \\
\text { research }\end{array}$ \\
\hline $\begin{array}{l}\text { Benefit sharing and access to } \\
\text { research results }\end{array}$ & $\begin{array}{l}\text { access and benefit sharing is } \\
\text { process of accessing resources } \\
\text { and sharing the benefits derived } \\
\text { from their use between the user } \\
\text { (countries using the resources) } \\
\text { and the provider (country } \\
\text { providing the resource) }\end{array}$ & $\begin{array}{l}\text { royalty payments, } \\
\text { intellectual property } \\
\text { rights, transfer of } \\
\text { resulting technology to } \\
\text { provider }\end{array}$ \\
\hline
\end{tabular}


Table 2. Proposed indicators and possible metrics of technology transfer in the context of the Convention on Biological Diversity (CBD), the targets they refer to under Strategic Goal E, and the potential biodiversity technology components these are most applicable to..

define stock and flow in a footnote;

\begin{tabular}{|c|c|c|c|c|c|c|c|}
\hline Indicator & Reference & Target number & $\begin{array}{l}\text { Technology } \\
\text { component }^{\mathrm{a}}\end{array}$ & Status & Type $^{b}$ & Data source & $\begin{array}{l}\text { Metric (plus additional } \\
\text { possibilities) }\end{array}$ \\
\hline $\begin{array}{l}\text { Number of global } \\
\text { biodiversity information } \\
\text { facility (GBIF) } \\
\text { records over time }\end{array}$ & $\begin{array}{l}\text { Biodiversity } \\
\text { Indicators } \\
\text { Partnership } 2013\end{array}$ & $\begin{array}{l}19 \text { (biodiversity } \\
\text { knowledge) }\end{array}$ & $\mathrm{BM}$ & implemented & stock & GBIF & $\begin{array}{l}\text { no records in specimen } \\
\text { databases }\end{array}$ \\
\hline $\begin{array}{l}\text { Number of maintained } \\
\text { species inventories being } \\
\text { used to implement the CBD }\end{array}$ & $\begin{array}{l}\text { Biodiversity } \\
\text { Indicators } \\
\text { Partnership, } 2013\end{array}$ & $\begin{array}{l}19 \text { (biodiversity } \\
\text { knowledge) }\end{array}$ & $\mathrm{BM}$ & $\begin{array}{l}\text { ready for global } \\
\text { and national use }\end{array}$ & stock & & $\begin{array}{l}\text { no. maintained species } \\
\text { inventories; accuracy of } \\
\text { species inventories (e.g., } \\
\text { number of species listed } \\
\text { multiple times); cost of } \\
\text { species inventories; no. } \\
\text { people trained in } \\
\text { database maintenance }\end{array}$ \\
\hline $\begin{array}{l}\text { Number of countries with } \\
\text { up-to-date national red lists } \\
\text { (NRLs) }\end{array}$ & & $\begin{array}{l}19 \text { (biodiversity } \\
\text { knowledge) }\end{array}$ & $\mathrm{BM}$ & possible & stock & $\begin{array}{l}\text { national reports } \\
\text { (www.nationalredlist. } \\
\text { org) }\end{array}$ & $\begin{array}{l}\text { no. NRLs using IUCN } \\
\text { categories and criteria; } \\
\text { no. NRLs that included } \\
\text { capacity building } \\
\text { workshops; no. red-list } \\
\text { assessors trained }\end{array}$ \\
\hline $\begin{array}{l}\text { Official development } \\
\text { assistance in support of the } \\
\text { CBD }\end{array}$ & $\begin{array}{l}\text { Biodiversity } \\
\text { Indicators } \\
\text { Partnership, } 2013 \\
\end{array}$ & $\begin{array}{l}\mathbf{2 0} \text { (resource } \\
\text { mobilization) }\end{array}$ & $\begin{array}{l}\text { BM, CONS, } \\
\text { SU, BIOT, } \\
\text { ABS }\end{array}$ & implemented & $\begin{array}{l}\text { stock \& } \\
\text { flow }\end{array}$ & spell out & $\begin{array}{l}\text { expenditure on CBD- } \\
\text { related projects }\end{array}$ \\
\hline $\begin{array}{l}\text { Spending per technology } \\
\text { transfer project }\end{array}$ & $\begin{array}{l}\text { Böhm \& Collen, } \\
2011\end{array}$ & $\begin{array}{l}\mathbf{2 0} \text { (resource } \\
\text { mobilization) }\end{array}$ & $\begin{array}{l}\text { BM, CONS, } \\
\text { SU, BIOT, } \\
\text { ABS }\end{array}$ & $\begin{array}{l}\text { for } \\
\text { consideration }\end{array}$ & $\begin{array}{l}\text { stock \& } \\
\text { flow }\end{array}$ & national reports & $\begin{array}{l}\text { expenditure per } \\
\text { technology transfer } \\
\text { project }\end{array}$ \\
\hline $\begin{array}{l}\text { Amount of royalties paid by } \\
\text { the private sector and re- } \\
\text { invested in the process }\end{array}$ & Pisupathi, 2010 & $\begin{array}{l}\mathbf{2 0} \text { (resource } \\
\text { mobilization) }\end{array}$ & $\mathrm{ABS}$ & $\begin{array}{l}\text { for } \\
\text { consideration }\end{array}$ & stock & national reports & $\begin{array}{l}\text { sum of royalties } \\
\text { payments }\end{array}$ \\
\hline $\begin{array}{l}\text { Level of national investment } \\
\text { associated with transfer of } \\
\text { relevant technologies }\end{array}$ & Pisupathi, 2010 & $\begin{array}{l}\mathbf{2 0} \text { (resource } \\
\text { mobilization) }\end{array}$ & $\begin{array}{l}\text { BM, CONS, } \\
\text { SU, BIOT, } \\
\text { ABS }\end{array}$ & $\begin{array}{l}\text { for } \\
\text { consideration }\end{array}$ & $\begin{array}{l}\text { stock \& } \\
\text { flow }\end{array}$ & national reports & investment expenditure \\
\hline $\begin{array}{l}\text { Personnel involvement in } \\
\text { technology transfer }\end{array}$ & $\begin{array}{l}\text { Böhm \& Collen, } \\
2011\end{array}$ & $\begin{array}{l}19 \text { (biodiversity } \\
\text { knowledge) }\end{array}$ & $\begin{array}{l}\text { BM, CONS, } \\
\text { SU, BIOT, }\end{array}$ & $\begin{array}{l}\text { for } \\
\text { consideration }\end{array}$ & Stock & $\begin{array}{l}\text { national reports } \\
\text { project-level }\end{array}$ & $\begin{array}{l}\text { full time equivalents } \\
\text { working on technology }\end{array}$ \\
\hline
\end{tabular}




\begin{tabular}{|c|c|c|c|c|c|c|c|}
\hline & & & ABS & & & monitoring & transfer projects \\
\hline $\begin{array}{l}\text { Status of human resource } \\
\text { development on technology } \\
\text { transfer }\end{array}$ & Pisupathi, 2010 & $\begin{array}{l}19 \text { (biodiversity } \\
\text { knowledge) } \\
\mathbf{2 0} \text { (resource } \\
\text { mobilization) }\end{array}$ & $\begin{array}{l}\text { BM, CONS, } \\
\text { SU, BIOT, } \\
\text { ABS }\end{array}$ & $\begin{array}{l}\text { for } \\
\text { consideration }\end{array}$ & $\begin{array}{l}\text { stock \& } \\
\text { flow }\end{array}$ & $\begin{array}{l}\text { national reports } \\
\text { project-level } \\
\text { monitoring }\end{array}$ & $\begin{array}{l}\text { number of people } \\
\text { involved in technology } \\
\text { transfer; no. full time } \\
\text { equivalent staff on } \\
\text { technology transfer }\end{array}$ \\
\hline $\begin{array}{l}\text { Number of CBD-specific } \\
\text { technology cooperation } \\
\text { projects, } \\
\text { schemes, and programs }\end{array}$ & Pisupathi, 2010 & $\begin{array}{l}19 \text { (biodiversity } \\
\text { knowledge) }\end{array}$ & $\begin{array}{l}\text { BM, CONS, } \\
\text { SU, BIOT, } \\
\text { ABS }\end{array}$ & $\begin{array}{l}\text { for } \\
\text { consideration }\end{array}$ & Stock & national reports & $\begin{array}{l}\text { number of projects with } \\
\text { technology transfer } \\
\text { component }\end{array}$ \\
\hline $\begin{array}{l}\text { Number and amount of } \\
\text { technology assessments, } \\
\text { transfers, incubations, and } \\
\text { uses accounted for CBD } \\
\text { Parties }\end{array}$ & Pisupathi, 2010 & $\begin{array}{l}19 \text { (biodiversity } \\
\text { knowledge) } \\
\text { Secondary: } \\
\mathbf{1 7} \text { (National } \\
\text { Biodiversity } \\
\text { Strategies and } \\
\text { Action Plans) }\end{array}$ & $\begin{array}{l}\text { BM, CONS, } \\
\text { SU, BIOT, } \\
\text { ABS }\end{array}$ & $\begin{array}{l}\text { for } \\
\text { consideration }\end{array}$ & $\begin{array}{l}\text { stock \& } \\
\text { flow }\end{array}$ & national reports & $\begin{array}{l}\text { number of technology } \\
\text { assessments }\end{array}$ \\
\hline $\begin{array}{l}\text { Number of regional and } \\
\text { national biodiversity } \\
\text { technology missions by the } \\
\text { CBD Parties }\end{array}$ & Pisupathi, 2010 & $\begin{array}{l}19 \text { (biodiversity } \\
\text { knowledge) } \\
\mathbf{2 0} \text { (resource } \\
\text { mobilization) }\end{array}$ & $\begin{array}{l}\text { BM, CONS, } \\
\text { SU, BIOT, } \\
\text { ABS }\end{array}$ & $\begin{array}{l}\text { for } \\
\text { consideration }\end{array}$ & $\begin{array}{l}\text { stock \& } \\
\text { flow }\end{array}$ & national reports & $\begin{array}{l}\text { number of regional and } \\
\text { national biodiversity } \\
\text { technology missions }\end{array}$ \\
\hline
\end{tabular}

a Abbreviations: BM, biodiversity or species monitoring; CONS, conservation (in situ or ex situ); SU, sustainable use of natural resources;

BIOT, biotechnology using genetic resources; ABS, access and benefits sharing.

${ }^{\mathrm{b}}$ Stock: metrics are taken at a single point in time; flow: metrics are taken over time and space through ancillary data on donor and recipients. 


\section{Figure legends}

Fig. 1. Conceptualization and spatial representation of technology transfer in the context of the Convention on Biological Diversity: (a) technology-rich countries aid biodiversity-rich countries and provide special provisioning for the least developed countries (least developed countries defined as per World Bank (2015)) and (b) multidirectionality of technology transfer through collaboration, cooperation, development, and conservation aid, among other strategies (letters, countries; arrows, direction of technology transfer; solid line, development of technology and hence transfer through collaboration/cooperation; dashed line, technology transfer through capacity building, buying power, etc.]).

Fig. 2. (a) The pressure-state-response framework and placement of current indicators relevant to the Convention on Biological Diversity (CBD), including the placement of a technology transfer indicator as a response indicator; (b) framework of the proposed, simplistic, yet achievable, technology transfer indicators that monitors flow from one country to all recipients (primarily least developed countries in keeping with the original purpose of technology transfer within the CBD context). The 5 CBD components are biodiversity/species monitoring, conservation (in situ/ex situ), sustainable use of natural resources, biotechnology using genetic resources, access and benefits sharing. Technology transfer measures are likely to be specific to one or more of these components. Stock metrics are introduced for both donor and recipient-side of technology transfer and help introduce quantity and type of flow into the indicator. 
Fig. 1.

A Direction of technology flow

High income, technology

Upper-middle income, some technology

Lower-middle income, some technology

Low income, lack of technology

B

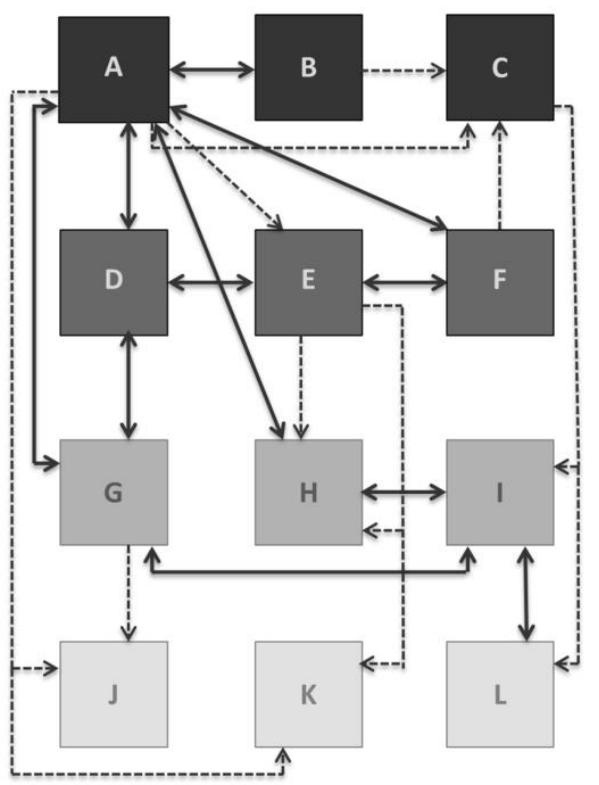

High income

Upper-middle income

Lower-middle income

Low income 
Fig. 2.

A

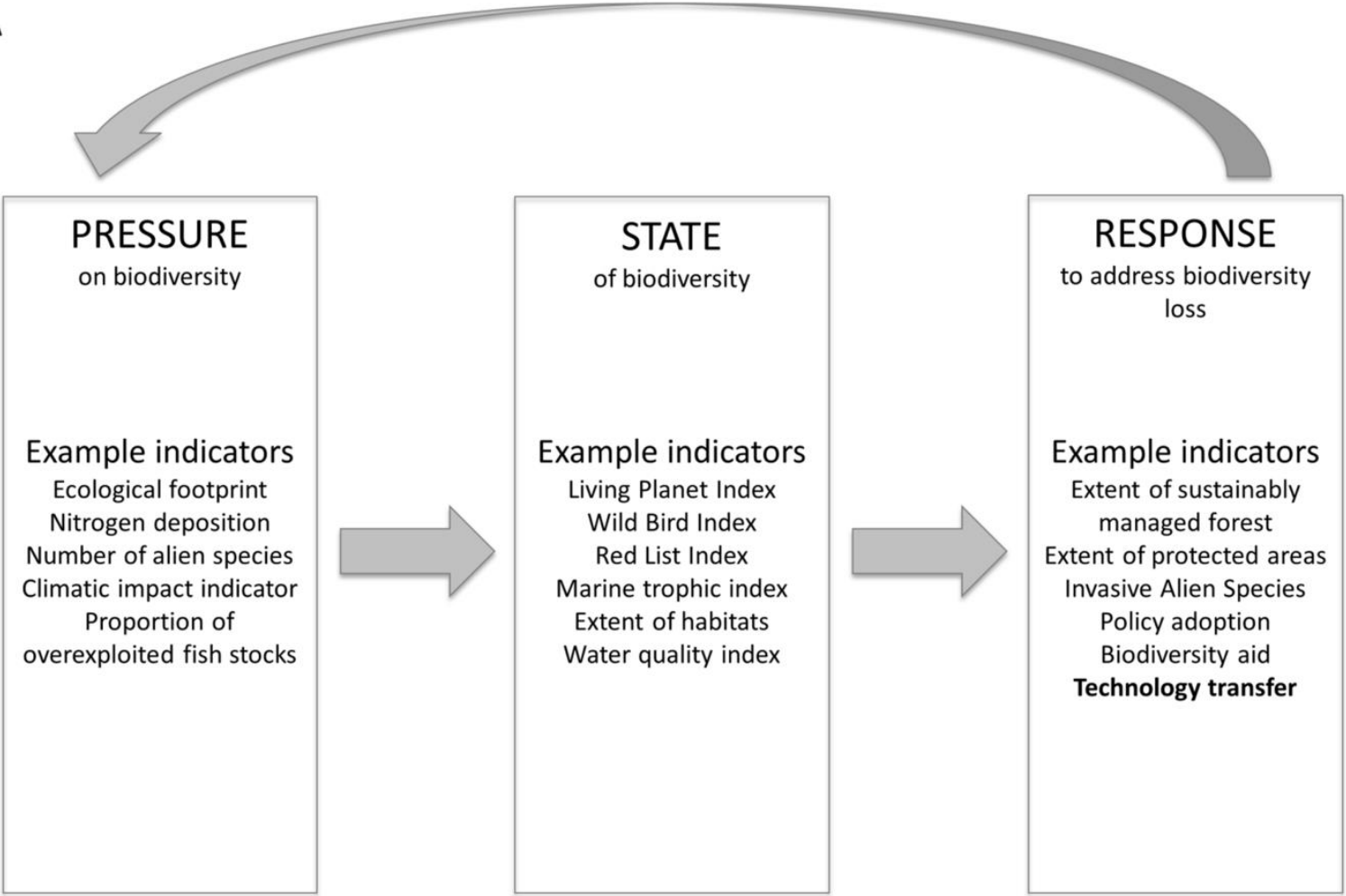

B

Flow of technology relevant to $5 \mathrm{CBD}$

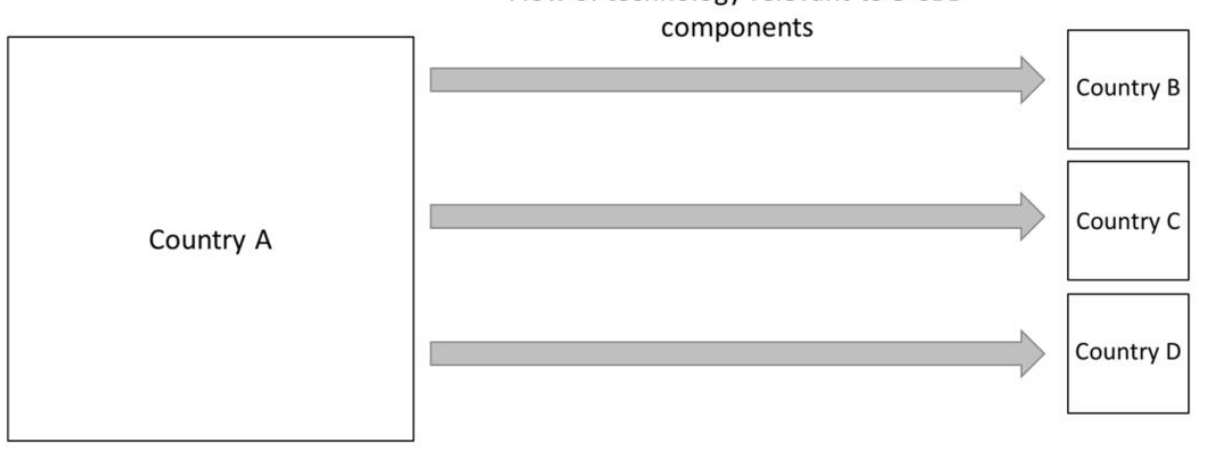

Potential stock metrics:

Potential stock metrics:

- Number of projects with technology transfer component

- Expenditure on technology transfer

- Human resources providing training in technology

Introduce flow by specifying recipient \& relating relevant metrics
- Number of projects with technology transfer component

- Investment in obtaining technology

- Human resources trained in technology

- Etc.

- Etc. 